\title{
The Relation between Accountability and the Climate of Service in Israeli Public organisations
}

\section{Yehuda ELIYA ${ }^{1}$ \\ Nicolae BIBU ${ }^{2}$}

\begin{abstract}
The paper discusses the findings of a doctoral research project about the relation between accountability and the climate of service in Israeli public organizations. It used a quantitative approach and targeted a number of 2798 respondents. The research population included managers and employees from six public organizations from Israel in autumn 2018l. The final sample comprised 1036 valid questionnaires.

The four hypothesis related to the topic were validated, and a positive correlation was found between accountability and service climate. It should be noted that the organization's "general accountability" showed weak correlation with "service climate". The conclusions point out that accountability of public organizations and of their employees is perceived as an important factor for enhancing the service climate in the public organizations, for increasing the citizen's confidence and creating public system fairness.
\end{abstract}

Keywords: public organization, accountability, climate of service, Israel, citizen.

JEL classification: $\mathrm{G} 20$, G 28, G 29

DOI: 10.24818/RMCI.2019.1.30

\section{Introduction}

If we discuss the development of the service climate in the public sector, there is a growing tendency in the present to change the perception that was accepted in the old bureaucratic organizations (Vigoda-Gadot, 2008). This change can be said to be reflected in the entry of the public sector, into a new era characterized by a marketing orientation, organizational flexibility, efficiency and responsiveness to citizens' needs. In addition to these aspects, awareness of the ability to control the functioning of the service for the public through quantitative control indicators for examining the satisfaction and public image of the public has increased in recent years (Vigoda-Gadot, Drory, 2016).

Wiley, Pugh and Dietz (2004) argued that the interaction between the organization and its clients is all the more important as the service climate as a factor of influence, perception and attitude of the beneficiaries of the organization's services. When we notice the changes that public institutes and organizations have implemented in managing and perceiving services in recent years, implementing the new public management (NPM), we come to the conclusion that there is no

\footnotetext{
${ }^{1}$ Yehuda Eliya, PhD candidate, West University of Timisoara

${ }^{2}$ Nicolae Bibu, West University of Timisoara
} 
way to return to the traditional public service. Our perception of how the public sector has to deal with public services needs to be characterized by a business vision and a vision that is predominant in top private sector business organizations.

\section{Accountability}

After consulting the literature, we note that there is still no satisfactory interpretation for the operative meaning of the term of liability in the public sector. In most cases, public sector responsibility is referred to as a term or as a principle that refers to a situation where something goes wrong when someone tries to get a case or gives a finger to the cause of failure (Conners et al., 1994). Liability is defined as "the individual's awareness of the responsibility he / she can have over the decision-making process and / or the execution of the decisions he / she has taken" (Tetlock, 1985). Responsibility is perceived as "transferable responsibility between medium echelons and low echelon" (De Haven-Smith \& Jenne, 2006). According to Schillemans (2010), public sector accountability also involves reacting to the leadership or bureaucratic echelons of the organization, to the organization's clients, and the environment in which the role is played. This approach takes into account the many stakeholders that the responsible person is responsible for, with customers being the majority who are interested in any organization.

In the literature, we have identified different types of responsibilities depending on the environment in which people work because of their profession, agreements between them and the beneficiaries of services, and many others. Among these types, common types of liability, such as bureaucratic / hierarchical responsibility, professional responsibility, market responsibility (DarlingHammond \& Ascher, 1991) and political and legal responsibility (Romzek \& Dubnick, 1994) can be found.

Erkkia (2007) refers to responsibility in a similar way. In addition, he argues that the opening component embedded in public decision-making and policy-making processes is a significant and integrated part of the concept of accountability in the public sector.

Romzek \& Ingraham (2000) argue that responsibility in its most basic sense refers to the ability to respond to any factor of expected performance. Roberts (2002) presents five aspects of responsibility in public organization:

- Transparency

- Liability

- Controllability

- Responsibility

- Responsiveness

Eun \& Wook (2010) are those referring to the term of responsibility that involves four areas of responsibility. First is the "hierarchical / bureaucratic" responsibility, which indicates strict supervision through the use of rules and regulations, training through supervision and fixed standards for performance 
measurement. The second type is "legal responsibility" which reflects an external, both comprehensive and detailed, vision of performance, which aims at maintaining the contractual relationship within the organization. The third is "professional liability", defined as the hope that employees in the organization will work on their expertise, professional standards and standards that are required. "Political accountability," the fourth is the one that refers to the organization's ability to react to its main stakeholders, ie government, community groups, customers and individual citizens.

Bolton (2003) argues that the public sector as well as the private sector are influenced by two main processes: the first is technological progress and the second represents the expectations of public customers. Expectations have changed when customers have more knowledge, become more educated and have a greater awareness of the environment. According to him, most business processes have improved due to new technologies that exist in the public sector. The world expects the public sector and non-profit organizations to be bigger.

The public sector's performance is lower than the private sector's performance and the public sector workers often claim that the reason for it is the poorer resource allocation than in the private sector. He claims that the truth is combined by those two claims and other additional components.

We consider that essential for the success of public sector organizations is the level of mission performance. Completing the mission includes additional factors in terms of being efficient, be responsible for public money and in terms of offering satisfactory service to clients. Lately, the expectation raises more and more and public organizations are forced to embrace methods of performance improvement that are implemented in private sector to prove accountability of their employees.

Most successful factors are supervised by government supervisors and internal auditors, etc., and some are supervised by the service recipient. It is competition that is a motivating factor for the improvement of the offices that provide services and which compete with the organizations in the private sector. Although for many public sector organizations competition does not exist, because governments do not allow private organizations to provide competing services to services provided by public organizations.

At present, regulatory precedents, legal decisions and statutory procedures formally establish external mechanisms that guarantee the responsibility of managers in the civil service (Bertelli, 2004). Responsibility is the ability to answer supervisors or their representatives and the responsibility of each public representative (Cooper, 1990). Responsibility is the duty of public organizations to serve the higher authority, which is public trust, as it is the source of the authority of those organizations. We can meet standards of responsibility in textbooks and rule rules. These are standards that express clear audience expectations for public officers. An indirect way to place these expectations is also expressed by implicit criticism of customers, taxpayers, money donors, the media and other stakeholders (Dubnick, 2005).

32 Review of International Comparative Management

Volume 20, Issue 1, March 2019 
Accountability necessarily involves standards and end parties. However, we consider that the concept of "accountability" represents a core value of the public administration, despite the differences of opinions regarding its interpretation. These differences are hidden under the cover of consensus regarding the importance and the necessity of this concept. Some studies refer to the concept accountability in the context of transparency, carrying responsibility and the ability to provide response during the process (Wood \& Winston, 2007). Other studies consider that accountability exists when referring to a situation in which something went wrong during the attempt to carry it and consists of aiming a finger of blame of the cause of failure (Conners et al, 1994).

In the academic literature we have identified several definitions of "accountability", discussed below. However, we have found that there are quite a few approaches that unite these very different definitions. One approach we have identified interprets the concept as responsibility for the performance (Romzak \& Dubnick, 1987), and a second one interprets accountability as responsibility for actions and decisions (Ranft, Ferris \& Perryman, 2007).

It is worthy to point out that we have also identified that in the last decade a trend among researchers and the general public in Israel that moves towards reaching a consensus about the interpretation of the term "accountability". Also, we can find a distinction between the term "accountability" and the term "accountable" in some definitions of the term "accountability" in academic literature. However, several researchers tend to present these the two terms as having the same meaning and using these terms alternatively, without a distinction between them (Mulgan, 2003, Bovens, 2007).

We consider that the concept of"accountability" still has not a satisfactory interpretation regarding its operational meaning for the public sector (Elyia, 2018). Usually, accountability is associated to the concept or to the principle that relates to a situation in which something goes wrong, (Conners et al, 1994), or is defined as awareness of the individual to the responsibility that he/she may have about his/her own judgments in the decision-making processes and/or about the implementation of the decisions that he/she took (Tetlock, 1985).

Also, accountability is considered, first, to be a responsibility that can be transferred hierarchically downwards from intermediate level towards a lower hierarchical level (De Haven-Smith \& Jenne, 2006), and, second, hierarchically upwards, it involves reporting to senior levels of the organizational or of the bureaucratic chain of command and to the environment in which the role holder acts (Kearns, 1996) (Schillemans, 2010). Accountability is perceived, explicitly or implicitly, in terms of reward and punishment (Cornell, et al., 2011). In a lot of countries there are many legal precedents, statutory decisions, regulations and procedures, officially set external mechanisms to ensure the responsible behavior of the managers in the public service (Bertelli, 2004). Cooper (1990) defines accountability as a responsibility to respond for your actions, results, decisions, way of thinking, and as an"answerability of officials towards controlling organizations". 
(Eliya, 2018) argues that "accountability in its purpose is the obligation of public organizations to serve a higher public authority, because citizens' trust in these public organizations is the source of their authority, in addition to their legal foundation". Currently, there are standards of accountability in the legal codes in force in every democratic country which are expressing the clear expectations of the public towards the public jobs holders. Another, indirect way of expressing these expectations, is the implicit critiques expressed by citizens in their double quality as tax-payers and as customers of public services, by taxpaying companies, by communities, by media and by other stakeholders.

On the other hand, it is also possible to define the concept accountability as the obligation of any individual to provide a report about his actions and answers of questions within the framework of their responsibility in their role, as individuals who are responsible for the organization activities and results (Ylimaki \& McClain, 2009).

Dubnic (2005), points out that the concept of accountability has two main components, first component is "warranty" or "responsibility", and second component is the duty to answer, "answerability" that is the responsibility for explaining or justifying one's actions to somebody for any question that is asked by hierarchical superiors or stakeholders. Similar to that, Romzek \& Ingraham (2000) are claiming that accountability, in its most basic sense, is referring to the obligation to report to anyone entitled about the expected performances.

The definition of "accountability" that we have adopted for our study is the definition given by Wood \& Winston (2007) which distinguishes between three dimensions of accountability. These dimensions are the following: first is the dimension of Responsibility, second, is the dimension of Openness, and third, the dimension of Answerability. Similar to this, Erkkila (2007) considers that the component of openness is embedded in decision making and in public policy making, as a significant and integral part of the concept of "accountability".

We conclude that there are some commonalities in the definitions of the term "accountability" such as: a). there are actors who expect from the role holder the execution of a particular action; b). the supervisory bodies or the general public (citizens, communities) expect the role holder to carry the responsibility for all specific fields of his/her activity; c). there is a way for the supervisory bodies to know when and how the task was performed, such as the right to receive an official report, either professionally or personally (Yitzhaki and Friedman, 2004), i.e., the duty of reporting consisting of providing accurate information or explanation to other people about how the role holder actions were performed and also about their results.

Philp (2009) presents a critical theory regarding the definition of accountability. He claimed that the issue of accountability is examined in terms of limiting of the judgment that is activated by holders of public job. He is also arguing that according to this theory, accountability is examined also in the terms of design of the mechanisms that should ensure providing the service in accordance with the accepted procedures. I consider that the definition of the accountability

34 Review of International Comparative Management

Volume 20, Issue 1, March 2019 
given by Romzek \& Dubnick (1987) and Eun \& Wook, (2010) is the most appropriate for use in our study since it refers to accountability in terms of both professional and political responsibility.

\section{Accountability in Public Organizations}

These studies have shown that the tendency of employees to carry the responsibility means a desire to meet the expectations and the strong feelings of responsibility. As a result of the set of expectations and relationships of trust management / employees, there is found a significant impact even on the actions of a particular individual. Employees who carry the responsibility will be aware to the measures that are needed for optimal performance of their work, their practices and their results will be fairly visible and transparent, and they will accept the expected assessment and their identification with the organization for the most part will be absolute (Rosenblatt, 2006).

Bolton (2003) argues that citizens are expecting that the public sector and non-profit organizations will carry greater responsibility of how their use of public money. The critical factor for the success of public sector organizations is the degree of performance of the mission. Fulfillment of the task includes the expectation of being effective, of carrying the responsibility of public money use and of offering a public service that satisfies the customers (beneficiaries). Consequently, public organizations are pressed into using private sector performance-enhancing methods based on increasing accountability among their employees.

Despite the extensive discussion about the meaning of the concept "accountability" in the systematic context, we have identified that only in the last two decades the discussion about the concept at the individual level began to be more intensive. Rosenblatt (2006) points out that the expectation of carrying responsibility at the individual level is not ending at the management level. According to her, accountability must be expected both from teachers and from other officials in the schools, so every employee is accountable to his/her superior manager and to his clients, that are the people who are paying directly or indirectly for the public service provided by the public servant.

Frink \& Ferris (1998) define accountability as being the implicit or explicit expectation that a person may be called to report to somebody in order to justify his/her beliefs, feelings and actions to others.

We consider that the key components identified in the two definitions, are the following: a) to report about the performance; b) the justifications; c) the reporting part and the supervisory audience that receives the reporting; 4) the feedback provided by the audience; 5) the rewards and sanctions, and 6) fairness. These definitions also imply the existence of agreed purposes or standards between the reporting body and the supervising body according to which the performances and the results are measured and next, are being rewarded or sanctioned. 
In the public sector, the term accountability at the individual level has a great importance due to the fact that it is about using public money, public resources. Both the term bureaucratic accountability (Adams \& Kirst, 1999) and the term professional accountability (Firestone \& Shipps, 2005), were developed in the public sector.

The term accountability at the individual level was discussed in the literature also with regard to various types of accountability and thus, we can evaluate closer to the essence of the term at the individual level. For example, bureaucratic/ hierarchical accountability is defined in the literature as the relationship between the responsibility holder and the recipient and the employer, which are based on a system of rules and regulations for the purpose of ensuring the implementation according to the existing standards and the achievement of planned organizational purposes. The policy is determined at the highest levels of the organization and is translated into processes that the managers determine. Consequently, the implementation of the policy in accordance with the procedures and the standards is bringing to accountability the employees of the public organisation.

Bureaucratic accountability is based on rules and regulations for the purpose that public organizations have to act according to the accepted standards and regulated processes.

In addition, the professional accountability differs from bureaucratic accountability in the nature of the relationships between the employee and the supervisor. Professional accountability is characterized by low control of the supervisors who control the professional employees; because the essence of the definition of the term is that the employee acts in accordance with the existing professional standards (Adams \& Kirst, 1999). Professional accountability is defined as the expectation from the employee to have accountability by virtue of his/her occupation with the profession. He/she is expected to be professional, to gain knowledge, to pass certification tests if they exist in his/her field of work and to perform his/her duties in accordance with the professional standards (DarlingHammond \& Ascher, 1991).

Frink \& Ferris (1999) conducted a study in which they examined the accountability in the individual level. In their study there was found that accountability among students affects the achievement of the purposes that they set for themselves at work. Rosenblatt (2006) also argues that, employees who feel accountability will be aware to the means that are needed for optimal performance of their work tasks they will be aware that their practices and their work results will be fairly visible and transparent to stakeholders, and that they will expect esteem and will accept it. Accountability is associated with commitment to the organization and the employees who consider themselves as who have accountability tend to remain loyal and related to the organization, a fact that ultimately strengthens the organization.

Frink \& Ferris (1998) examined the variable of accountability at the individual level and found a positive relation between this variable and the 
improvement of the performances of the individual. In their study there was found that accountability among students, affect the promotion of the purposes that they set for themselves at work.

The tendency of the employees to accountability means a desire to meet expectations, strong feelings of accountability and usually also has a significant impact on the actions of a particular individual in the organization. Employees who feel accountable for their work will be aware to the means that are needed for achieving optimal performance in their work, their practices and their results will be relatively visible and transparent and they will receive evaluation and will expect it (Rosenblatt, 2006).

\section{Organizational climate}

Organizational climate represents a system of feelings in relation to the formal and informal organization values that are translated by the individual and is based on the policies, goals and products of the organization (Tesluk, Vance and Mathieu, 1999).

The organizational climate perception affects the behavior of the members of the organization and is related to organizational effectiveness (Sparrow and Gaston, 1996). Organizational climate expresses the individual's perception of social processes and organizations within the work environment. The complexity and differences in social processes and organizations create perceptions that relate to a number of different climate systems. For example, a political climate derives from the translation of internal political processes, a climate of participation deriving from the translation of feelings of shared problem-solving and decisionmaking processes in the organization (Schneider and Bowen, 1985; Schneider, 1990).

Researches show that an organizational climate has an impact on employee performance on the intra-role and extra-functional levels (Sparrow and Gaston, 1996; Reichers and Schneider, 1990). One of the most studied aspects of employee performance in recent years is the issue of the Organization Citizenship BehaviorOCB, Behavior that constitutes a component of performance on the extrafunctional plane. Organization Citizenship Behavior is defined as individual behavior that is not directly recognized by the formal compensation system in the organization and which promotes organizational efficiency and effectiveness (Organ, 1988).

Organization Citizenship Behavior indicated that this variable reflects the interaction between the employees and managers in the organization. Social environment and support from the direct supervisor are components that influence the interaction between the individual and the organization and create an affinity for motivating the individual to engage in voluntary and contributing behavior (Van Yperen et al., 1999).

The beginnings of research in the field of organizational climate touched upon the climate as representing the personality of the organization (Forehand and 
Gilmer, 1964). Litwin and Stringer (1968) were among the first researchers to formulate the concept of organizational climate, defining it as a set of conditions and situations that affect the group's basic course of life.

Tagiuri (1968) defined an organizational climate as the quality of the internal environment in an organization that (a) is experienced by members of the organization, (b) influences their behavior, and (c) is described in terms of environmental attributes. Schneider (1975) defined an organizational climate as an array of generalized perceptions stemming from micro perceptions of certain events, conditions, and experiences through psychological processes of abstraction and conceptualization.

The conceptualization of the concept was first proposed by Pritchard and Karasick (1973). These researchers claimed that an organizational climate expresses a relative characterization of the internal organizational environment that distinguishes it from other organizations: (a) it derives from the behavior and policy of the members of the organization, (b) Serves as a basis for the emergence of the condition, and (c) acts as a source of activity and behavior.

Jones and James (1979) interpreted climate as a system of social and organizational psychological processes and defined it as an array of relevant concepts, characteristics, events, and processes of the organization. At the individual level, these perceptions present a cognitive translation of the organizational context and perception of the situation. Churchill, Ford and Walker (1976) maintain that an organizational climate is perceptions and assumptions about workplace, work situations, and the nature of interpersonal relationships between employees. These perceptions allow employees to appreciate the work environment and workplace.

Sparrow and Gaston (1996) also referred to the outcomes of the organizational climate and defined this concept as "representing a system of sensations in relation to the formal and informal organizational values translated by the individual and based on the policies, objectives and products of the organization" (p. 680).

This perception affects the behavior of members of the organization and is related to organizational effectiveness. Tesluk, Vance and Mathieu (1999) supported this approach and claimed that the definition of Sparrow and Gaston (1996) is currently accepted in the study of organizational climate. This definition will also be used in this study.

Organizational climate includes multi-dimensionality and is based on a combination of personal, social, and organizational concepts (Glick, 1985). The combination of these elements creates the organizational climate. As I claimed earlier in the literature, there are different classifications for an organizational climate: a climate of security, an organizational climate of safety (Neal and Griffin, 2002), a climate of service (Sparrow and Gaston, 1996), an organizational climate of innovation (Scott and Bruce, 1994), an organizational climate of trust (Colquitt, et al, 2002), the climate of ethics (Deshpande, 1996), an organizational climate of recognition (Sparrow, 2001), an organizational climate of support (Kozlowski and 
Doherty, 1989) (Sparrow and Gaston, 1996), and an organizational climate of participation (Tesluk and Mathieu, 1999), four types of climates (participative, innovative, leadership and service) impact employees' performance and public service outcomes, (Dana et al. (2012).

\section{Service climate}

(Schneider et al, 2009 defined a climate as a meaning given by workers to the policies, practices, processes, and behaviors supported and compensated by the organization, and by (Schneider et al, 1998) as shared perceptions of employees and relating to methods, processes and behaviors, which are rewarded and evaluated in terms of customer service and quality of service. The service climate is a general trend in service provision, emphasizing human resource management approaches, defining customer-oriented management priorities (Dean and Rainnie, 2009).

In more detailed manner, Schneider and Bowen (1993) defined the organizational climate through four main dimensions: (1) Management behavior management behavior in the chain of management that relates to the planning, organization and management of the service. (2) System support, that is support for the service through marketing, the appropriate personnel and operation of the systems in the service organization. (3) Customer focus and retention, that refers to internal organizational behavior which shows the importance of customers for the organization. (4) Logistic support, referring to the availability of tools, equipment and supplies required for the delivery of the service. An organization that has a service climate rewards its outstanding employees for good service (Vigoda-Gadot and Mizrahi, 2008). The service climate is of paramount importance to the functional dimension of the service (Mayer, Ehrhart and Schneider, 2009). Organizations seeking quality service are required to maintain and maintain the service climate in the organization (Johnson, 1996).

Many researchers (Schneider and Bowen, 2009; and Rainer, 2009) claim that the service climate rests on the foundations of basic support provided by the organization through resources, training, management approaches, and assistance required for effective performance. Walker (2007) claims that examining the quality of the service climate is based on how the organization employs methods and behaviors to achieve quality service.

This is reflected in areas such as management support for service providers, maintenance of skilled teams, and training of employees to expand their knowledge of service, and recognition and reward for service performance. The service climate gives employees a message about the issues that are important to the organization, the attitudes and behaviors expected of employees (Little and Dean, 2006). The perception of the climate the service is particularly central in the service sector where quality of service is a primary value (Poujol, 2009).

The impact of the service climate on the organization's productivity in the service sector is presented by Schneider et al. (2009) who claim that the 
significance given by employees to the service climate in their work affects the degree of attention given by the employees to the quality of the service. For their part, customers experience the behavior of the service providers affected by the organizational climate. As a result of these service experiences, customers arrive at the conclusions organization as to the quality of the service they received, conclusions that affect their satisfaction.

There is a growing trend in the development of a service climate in the public sector today (Vigoda-Gadot, 2008). This change is reflected in the entry of the public sector into a new era characterized by marketing orientation, organizational flexibility, efficiency and responsiveness to citizens' needs. In addition, awareness has grown in recent years regarding the control of the functioning of the service provided to the public through quantitative control measures to examine the public image's satisfaction and image (Vigoda-Gadot and Drory, 2016).

Wiley, Pugh and Dietz (2004) claim that the higher the interaction between the organization and its customers, the greater the importance of the service climate as a factor influencing the perceptions and attitudes of service recipients. When we examine the change that public organizations and institutions have undergone in management and service concepts in recent years, the concepts of new public administration (NPM) we understand that there is no turning back to traditional public administration. The perceptions of how the public sector should act in the areas of service provided to the public should be characterized by an employment perspective similar to that practiced in the private sector.

\section{Research methodology}

We have formulated 12 research hypotheses, out of which the following 4 are related to the topic of this article:

$\mathrm{H}_{6} \quad$ There will be positive correlation between accountability and service climate

$\mathrm{H}_{7}$ There will found positive correlation between the accountability indices and service climate

$\mathrm{H}_{8}$ There will be positive correlation between employees' accountability and service climate

$\mathrm{H}_{9}$ There will found positive correlation between the employees' accountability indices and service climate

The questionnaire is a structured questionnaire that includes five parts that describe the research variables (Appendix A). Part A: A questionnaire that examines the independent variable - the leadership style of the direct department manager from the employee's point of view. Part B: A questionnaire that examines the variable - the degree of accountability of the direct department manager from the employee's point of view. Part C: A questionnaire that examines the dependent variable - the climate of service in the organization. Part D: A questionnaire that

$40 \quad$ Review of International Comparative Management

Volume 20, Issue 1, March 2019 
examines the dependent variable - the accountability in the organization. Part E: Background variables - gender, age, seniority at work, education, income level and marital status.

\section{The research variables}

Accountability is defined as the degree to which the leader demonstrates openness, bears responsibility and gives the extent to which the leader has the ability to respond to his/her actions (Wood and Winston, 2005). They also defined three criteria for assessing the level of accountability among leaders: responsibility, openness, and answerability - and the ability to respond.

In the light of the large number of items in the questionnaire, it was decided to reduce the number of items that examines each of the concepts that define accountability. After reviewing the factor analysis that was conducted by Wood and Winston (2007), the five items that define each concept were selected, for which the highest value of Factor-Loads was accepted. The measurement was performed using a Likert scale ranging from 1 to 5 , with the lowest polar answer being 1 "completely disagree" and 5 "very agree" which is the highest polar answer.

The study used as definition for "Service climate" the extent to which the employee assesses the activity and skills of the entities within the organization, both at the managerial level and at the employee levels, in order to provide quality service. The service climate of the organization was examined using the Global Service Climate questionnaire which was developed by Schneider et al. (1998), which contains 7 items to examine this variable.

The variable "Accountability of employees" ( at individual level) was measured using a questionnaire, on the Likert 1-5 scale. The questionnaire examined the variable of accountability and was taken from a comprehensive index of the "Individual Contribution to Culture of Organizational Learning" questionnaire, which based on the "Questionnaire for Characterizing the Learning Culture from Experience in Organizations", as presented and validated by Ellis, Caridi, Lipshitz, and Poper (1999) and with validity of $\alpha=0.7634$. The questionnaire contains 11 items that measure the accountability variable. The items that examined the value of the accountability were changed by the authors of the study in order to adjust them to this study and presented as questions at the individual level.

\section{Discussion of the results}

The research method that was used was a quantitative one. The research population included managers and employees from six public organizations from Israel. These six public organizations are the following: the Ministry of Finance and Income Tax Authority, the National Insurance Institute, the Ministry of the Interior, Ministry of Welfare, Ministry of Health and Ministry of Education. The 
research population was selected for its heterogeneity in different levels and the researchers' accessibility to the relevant data. The research sample included 1036 employees and managers. Table 1 presents the sample of the research population's divided by public organizations.

Descriptive characteristics of the research population

Table 1

\begin{tabular}{|l|c|c|c|c|}
\hline \multicolumn{1}{|c|}{ Public organisation } & \multicolumn{4}{|c|}{ Questionnaires } \\
\hline Ministry of Finance & Distributed & Collected & $\begin{array}{c}\text { Response rate } \\
\text { (RR) }\end{array}$ & $\begin{array}{c}\text { Rate of total } \\
\text { sample }\end{array}$ \\
\hline Ministry of Welfare & 221 & 139 & $62.93 \%$ & $13 \%$ \\
\hline National Insurance Institute & 160 & 137 & $85.63 \%$ & $13 \%$ \\
\hline Ministry of the Interior & 300 & 221 & $73.67 \%$ & $21 \%$ \\
\hline Ministry of Health & 647 & 243 & $37.58 \%$ & $23 \%$ \\
\hline Ministry of Education & 500 & 154 & $30.80 \%$ & $15 \%$ \\
\hline Total & 970 & 142 & $14.64 \%$ & $14 \%$ \\
\hline
\end{tabular}

Each employee / manager of the involved public organizations filled a questionnaire which included several demographic data and the indices of the independent variables, sets of questions referring the variables of leadership, accountability and service climate and questions referring the variable performance of the public organization. The questionnaire's filling time was about 20 minutes. The employees and the managers who were gathered for this purpose had a general explanation about the research and its nature and the research's maximal anonymity and the information immunity from intra-organizational and extra-organizational factors were emphasized to them. The questionnaires were collected at the site, in order to get maximal response rate. At the same time, each employee / manager had the possibility to submit the filled questionnaire directly to the researcher in person or by mail, in order to ensure maximum of anonymity and get correct answers to the questionnaire.

Descriptive statistics of the research sample

Table 2

\begin{tabular}{|l|l|c|c|c|c|}
\hline Variable & \multicolumn{1}{|c|}{ Categories } & Mean & $\begin{array}{c}\text { Standard } \\
\text { deviation } \\
\text { S.D. }\end{array}$ & $\begin{array}{c}\text { Range } \\
\mathbf{R}\end{array}$ & $\begin{array}{c}\text { Percentage } \\
\text { of the sample } \\
\text { n=1036 }\end{array}$ \\
\hline Age & Years & 41.65 & 11.13 & 55 & 96.5 \\
\hline Gender & $\begin{array}{l}\text { Male }=0 \\
\text { Female }=1\end{array}$ & -- & -- & -- & 30.7 \\
\hline Education & Years of studies & 14.10 & 5.62 & 25 & .693 \\
\hline Position & 1= Manager & -- & -- & -- & 36.8 \\
\cline { 2 - 6 } & 2= Front line employee & -- & -- & -- & 41.6 \\
\cline { 2 - 6 } & 3=Other & -- & -- & -- & 7.8 \\
\hline
\end{tabular}




\begin{tabular}{|c|l|c|c|c|c|}
\hline Variable & Categories & Mean & $\begin{array}{c}\text { Standard } \\
\text { deviation } \\
\text { S.D. }\end{array}$ & $\begin{array}{c}\text { Range } \\
\mathbf{R}\end{array}$ & $\begin{array}{c}\text { Percentage } \\
\text { of the sample } \\
\mathbf{n = 1 0 3 6}\end{array}$ \\
\hline & $\begin{array}{l}\text { 4= employee embedded } \\
\text { in an administrative } \\
\text { standard of a manager }\end{array}$ & -- & -- & -- & 15.5 \\
\hline
\end{tabular}

Table 2 presents the general characteristics of the research population. The total research population included 2798 managers and employees. 1036 managers and employees gave back the fully filled questionnaires. The response rate was very good $37.03 \%$. The research population's gender included $30.7 \%$ male and $69.3 \%$ female participants. The average age of responding managers and employees was 41.65 years old (standard deviation of 11.13 years), the average education of the research population was 14.1 years (standard deviation of 5.62 years), higher than high school education (12 years of study). There were $38 \%$ of managers (394) and $52.2 \%$ employees (541), while 103 of the sample participants reported a different position in work $(9.8 \%)$.

The perceptions of employees from the public sector organizations about "accountability" were divided in two: perceptions concerning "general accountability" and perceptions regarding "employees' accountability". "General accountability" was divided into three indices: "responsibility", "openness" and the "ability to respond". From Table 3 it can be seen that the "general accountability" evaluation average is medium high (mean $=3.57 ; \mathrm{SD}=.66$ ). The "responsibility" index is perceived in high level (mean $=3.68 ; \mathrm{SD}=.86$ ) and the other accountability indices: the "Openness" index and the "Ability to respond" index are evaluated at a similar level (mean 3.47, 3.54 in accordance).

\section{Characteristics of the main research variables}

\begin{tabular}{|c|c|c|c|c|c|c|c|}
\hline Variable & 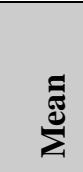 & 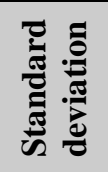 & 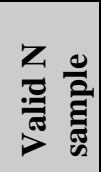 & $\begin{array}{l}\stackrel{\infty}{0} \\
\stackrel{\Xi}{*} \\
\simeq\end{array}$ & 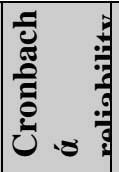 & 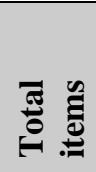 & 苞 \\
\hline Transformational leadership & 3.16 & .56 & 1036 & 6.38 & .87 & 20 & $5-1$ \\
\hline Ethical value influence & 3.33 & .73 & 989 & 4.00 & .91 & 9 & $5-1$ \\
\hline Intellectual challenge & 2.76 & .76 & 1023 & 4.00 & .58 & 2 & $5-1$ \\
\hline $\begin{array}{l}\text { Motivation through } \\
\text { inspiration }\end{array}$ & 3.40 & .94 & 1031 & 4.00 & .79 & 4 & $5-1$ \\
\hline Personal attention & 3.19 & 1.00 & 933 & 4.00 & .59 & 5 & $5-1$ \\
\hline Transactional leadership & 3.52 & .81 & 1033 & 4.00 & .91 & 12 & $5-1$ \\
\hline Conditioned reward & 3.91 & .87 & 1030 & 4.00 & .82 & 4 & $5-1$ \\
\hline Active corrective leadership & 3.43 & .90 & 1027 & 4.00 & .85 & 4 & $5-1$ \\
\hline $\begin{array}{l}\text { Passive corrective } \\
\text { leadership }\end{array}$ & 3.22 & 1.02 & 1024 & 4.00 & .89 & 4 & $5-1$ \\
\hline Lack of leadership & 3.35 & 1.00 & 1029 & 4.00 & .82 & 4 & $5-1$ \\
\hline General accountability & 3.57 & .66 & 1034 & 4.00 & .90 & 15 & $5-1$ \\
\hline
\end{tabular}




\begin{tabular}{|c|c|c|c|c|c|c|c|}
\hline Variable & $\sum_{\Sigma}^{\bar{E}}$ & 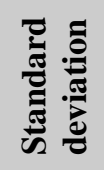 & 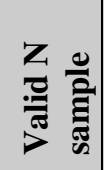 & 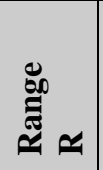 & 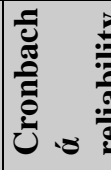 & 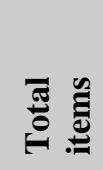 & 芴 \\
\hline Responsibility & 3.68 & .86 & 1025 & 4.00 & .86 & 5 & $5-1$ \\
\hline Openness & 3.47 & .75 & 1020 & 4.00 & .76 & 5 & $5-1$ \\
\hline Ability to respond & 3.54 & .77 & 960 & 4.00 & .88 & 5 & $5-1$ \\
\hline Service climate & 3.45 & .72 & 1029 & 4.00 & .83 & 7 & $5-1$ \\
\hline $\begin{array}{l}\text { Service climate rate - } \\
\text { employees }\end{array}$ & 3.55 & 1.04 & 1018 & 4.00 & -- & 1 & $5-1$ \\
\hline $\begin{array}{l}\text { Service climate rate - } \\
\text { management }\end{array}$ & 3.38 & .84 & 1021 & 4.00 & .77 & 3 & $5-1$ \\
\hline $\begin{array}{l}\text { Service climate rate }- \text { the } \\
\text { organization }\end{array}$ & 3.52 & .85 & 950 & 4.00 & .87 & 3 & $5-1$ \\
\hline Employees' accountability & 3.79 & .67 & 1025 & 4.18 & .82 & 11 & $5-1$ \\
\hline $\begin{array}{l}\text { The organization's } \\
\text { performance }\end{array}$ & 3.78 & .75 & 988 & 4.00 & .86 & 4 & $5-1$ \\
\hline
\end{tabular}

The dependent variable "Service climate" is defined as the combination of employees' feelings concerning the rewards system and the procedures for qualitative service in the organization that creates a service climate perception system. The qualitative service climate perception was measured by grading the climate referring the employees, service climate that refers to management and leadership and service climate grading. As presented in the above Table 3, these variables are reliable and were gathered to one variable, "Service climate". The primary basis of our research is discussing the relation between service climate and management and leadership in the organization. Table 4 presents the correlation matrix between service climate and transformational leadership, transactional leadership, lack of leadership, accountability and performance.

\section{Person's correlation of the main variables (Cronbach $\alpha$ in parentheses)}

\begin{tabular}{|ll||rrrrrrr|}
\hline \multicolumn{1}{|c|}{ Variable } & $\mathbf{1}$ & $\mathbf{2}$ & $\mathbf{3}$ & $\mathbf{4}$ & $\mathbf{5}$ & $\mathbf{6}$ & $\mathbf{7}$ \\
\hline \hline 1 & Service climate & $(.83)$ & & & & & & \\
2 & $\begin{array}{l}\text { Transformational } \\
\text { leadership }\end{array}$ & $.50^{* *}$ & $(.87)$ & & & & & \\
3 & Transactional leadership & $.63^{* *}$ & $.59^{* *}$ & $(.92)$ & & & & \\
4 & Lack of leadership & $-.33^{* *}$ & $-.16^{* *}$ & $-.43^{* *}$ & $(.82)$ & & & \\
5 & Accountability & $.57^{* *}$ & $.54^{* *}$ & $.69^{* *}$ & $-.39^{* *}$ & $(.90)$ & & \\
6 & Employees' accountability & $.76^{* *}$ & $.45^{* *}$ & $.75^{* *}$ & $-.47^{* *}$ & $.45^{* *}$ & $(.82)$ & \\
7 & Performance & $.68^{* *}$ & $.46^{* *}$ & $.59^{* *}$ & $-.37^{* *}$ & $.53^{* *}$ & $.74^{* *}$ & $(.86)$ \\
\hline
\end{tabular}

44 Review of International Comparative Management

Volume 20, Issue 1, March 2019 


$$
\mathrm{N}=943-1036 \quad \mathrm{NS}=\text { Not Significant } \quad \mathrm{P}<.01 * * \quad \mathrm{P}<.05 *
$$

As my research model suggested, the organization's employees' perception regarding the service climate influenced the perception regarding the leadership type in the organization, accountability in the organization and employees' accountability. A multivariate regression was performed to examine the prediction ability of the research variables on the dependent variable "service climate". The results are presented in Table 5, below.

\section{Multivariate regression to "service climate" variable}

Table 5

\begin{tabular}{|l|l|l|l|}
\hline Independent variable & Beta & T & Sig \\
\hline Transformational leadership & .097 & 3.753 & .000 \\
\hline Transactional leadership & .073 & 2.056 & .040 \\
\hline Lack of leadership & -.025 & -1.046 & .296 \\
\hline Accountability & .051 & 1.704 & .039 \\
\hline Employees' accountability & .625 & 17.926 & .000 \\
\hline
\end{tabular}

$\mathrm{F}=286.7 \mathrm{df}=5$

$\begin{array}{lll}\text { R Square } & \text { Adjusted R Square } & \begin{array}{l}\text { Std. Error of } \\ \text { the Estimate }\end{array} \\ .587 & .585 & .46550\end{array}$

The model presented in the current regression equation explains $58.7 \%$ of all the explained variance $(\mathrm{R} 2=0.587)$ of the dependent variable "Service climate". The equation itself was found significant $(\mathrm{F}=286.767 ; \mathrm{p}<0.05 ; \mathrm{df}=5$,). The variables that influence the service climate are the following: employees' accountability (Beta $=0.625 ; \mathrm{p}<0.05)$, general accountability (Beta=0.051; $\mathrm{p}<0.05)$.transformational leadership (Beta $=0.097 ; \mathrm{p}<0.05$ ), transactional leadership $(B e t a=0.073 ; \mathrm{p}<0.05)$. The variable "Lack of leadership" was not found as influencing the service climate due to its insignificance ( $p>0.05)$.

\section{Excerpt from the summary of research hypotheses examination}

\begin{tabular}{|l|l|c|}
\hline Number & \multicolumn{1}{|c|}{ Hypothesis } & Validity \\
\hline H6 & $\begin{array}{l}\text { There will be positive correlation between accountability and } \\
\text { service climate }\end{array}$ & Yes \\
\hline H7 & $\begin{array}{l}\text { There will be positive correlation between the accountability } \\
\text { indices and service climate }\end{array}$ & Yes \\
\hline H8 & $\begin{array}{l}\text { There will be positive correlation between employees' } \\
\text { accountability and service climate }\end{array}$ & Yes \\
\hline H9 & $\begin{array}{l}\text { There will be positive correlation between the employees' } \\
\text { accountability indices and service climate }\end{array}$ & Yes \\
\hline
\end{tabular}


Hypotheses H6-H9 are referring to the correlation between the "general accountability" of the public organization and the "service climate" of the public organization and the correlation between the public organization "employees' accountability" and the "service climate" of the public organization.

All the four hypotheses were validated and a positive correlation was found between accountability and service climate (see Table 5). Also, it should be noted that the organization's "general accountability" showed weak correlation with "service climate" (see Table 5).

Employees' accountability for his/her actions and their consequences (Karidi, 1997) and learning from the results of their actions is important to public organizations. When the individual or the team responsible for failure considers themselves as guilty, even if it is not true, they do not seek other factors to blame for the failure, and thus they are committed to find what was wrong so next time they will avoid the mistake. This is the key to constant learning and improvement.

Since the 1990's, there is greater interest in the term accountability in both the academic literature and the daily discourse. A growing interest in human rights and democracy in the world has instilled the term among the citizen as electorate, that are seeking accountability of public organizations and from their employees, too, more than ever (Burgess, 1992, Mulgan, 2003, Bovens, 2010), and, subsequently, there is a greater demand for accountability. Each authorized representative is usually required to report under which authority it acts and every institution sees that holding an authority may be required to justify its actions to a higher superior authority (Robertson, 2004).

The beginning of the new century emphasizes technological improvements and followed the 1980s trend that made public services in Israel more service oriented, driven by processes and outputs, based on clear performance indices and improvement of public organizations' management (Vigoda-Gadot \& Meiri, 2008). In many public organizations, the employee's salary is incorporated in collective agreements, which limits the organization's ability to encourage a service climate and service orientation by offering salary or material benefit, subject to meeting performance and service objectives.

The research findings show that accountability has significantly positive and strong influence on the service climate in Israeli public organizations. This finding emphasizes the great importance of encouraging and strengthening accountability in public service-oriented organizations, and in their constant quest to improve work and processes in the organization (Vigoda-Gadot et al., 2007). According to this research results, accountability is a significant tool in developing service climate, which is likely to help improve the service the citizen will get from public service organizations.

\section{Conclusions regarding the Israeli public sector organizations}

Many governments act to improve their public image. The public sector image refer to its reputation and prestige level and how much it is valued by the

46 Review of International Comparative Management

Volume 20, Issue 1, March 2019 
citizens as a system that is good to work in and interact with (Vigoda-Gadot \& Mizrachi, 2008). The public sector's image for citizens is based on the general impression of this sector, which stems from the public's experience in its contact with the public sector (Wright et al, 2011). The public sector positive image will be affected by positive contacts (such as: efficient service, responding to the citizen's needs) that the citizen has with the public organizations as reflected in the public sector service climate. Consequently, transparency towards citizen is very important for the public image of the public system. This trend has accelerated in the last few years (Vigoda Gadot and Cohen, 2015). In this respect, accountability of public organizations and of their employees is perceived as an important factor for enhancing the service climate in the public organizations, for increasing the citizen's confidence and creating public system fairness.

\section{References}

Bibu, N., Ghanim, B. (2018) - Accountability, Taking Responsibility and Protection of Minorities and their Influence on the Police Organization Performance. Romanian International Management Review, vol. 19, issue 3.

Bertelli, A. M. 2004. Strategy and Accountability: Structural Reform Litigation and Public Management. Public Administration Review. 64. (1). pp. 28-42.

Bolton, M. 2003. Public Sector Performance Measurement: Delivering Greater Accountability. Work Study, 52, 1, 20-24.

Bovens, M. 2007. New Forms of Accountability and EU-Governance. Comparative European Politics. 4, 104-120.

Bovens, M. 2010. Two Concepts of Accountability: Accountability as a Virtue and as a Mechanism". West European Politics, 33.

Burgess, T. 1992. Accountability with Confidence. In: T. Burgess (Ed.), Accountability in School. UK: Longman Group.

Colquitt, J. A., Noe R. A., Jackson C. L. (2002). Justice in teams: antecedents and consequences of procedural justice climate. Personnel Psychology,

Conners, R., Smith, T. and Hickman, C. 1994. The Oz Principle: Getting Results through Individual and Organizational Accountability. Prentice Hall, NJ.

Cooper, T. 1990. The Responsible Administrator: An Approach to Ethics for the Administrative Role. San Francisco: Jossey-Bass Publishers.

Churchill, G.A., Ford, N. M., \&Walker, O. C. (1976). Organizational climate and job satisfaction in the sales force. Journal of Marketing Research, 13.

Dana R., Vashdi D R, Vigoda-Gadot E, Shlomi D. (2012). Assessing Performance: The Impact Of Organizational Climates And Politics On Public Schools' Performance, Public Administration.Volume 99, Issue 1 
Darling-Hammond, L. and Ascher, C. 1991. Accountability Mechanism in Big City School Systems. ERIC Clearinghouse on Urban Education New York, Digest 17.

De Haven-Smith, L. and Jenne, K. C., II. 2006. Management by Inquiry: A Discursive Accountability System for Large Organizations. Public Administration Review. (66). (1). pp. 64-76.

Dean, A. M. andRainnie, R. 2009. Frontline Employees' Views on organizational Factors that Affect the Delivery of Service Quality in Call Centers. The Journal of Services Marketing. 23. (5). pp. 326- 337.

Deshpande, S P, 1996, The impact of ethical climate types on facets of job satisfaction: An empirical investigation. Journal of Business Ethics, Volume 15, Issue 6.

Dubnick, M. 2005. Accountability and the Promise of Performance: In Search of the Mechanisms. Public Performance and Management Review. 28. (3). pp. 376-417.

Ellis, S., Caridi, O., Lipshitz, R., Popper, M. 91999). Perceived error criticality and organizational learning: an empirical investigation. Knowledge and Process management, Volume 6, Issue 3

Erkkila, T. 2007. Governance and Accountability: A Shift in Conceptualization. Public Administration Quarterly. 31 (1), pp. 1-38.

Eun Kim, S., and Wook Lee, J. 2010. Impact of Competing Accountability Requirements on Perceived Work Performance. The American Review of Public Administration. 40. 1. pp. 100-118.

Forehand, G. A., Gilmer, B. V. H. (1964), "Environmental variation in studies of organizational behaviour", Psychological Bulletin, Vol. 62, No. 6, pp. 361-382.

Glick, W.H., (1985). Conceptualizing and Measuring Organizational and Psychological Climate: Pitfalls in Multilevel Research, Academy of Management Review, Vol. 10, No. 3.

Jones, A. P. and James, L. R. (1979). 'Psychological climate: Dimensions and relationships of individual and aggregated work environment perceptions', Organizational Behavior and Human Performance, 23.

Johnson, J. W. 1996. Linking Employee Perceptions of Service Climate to Customer Satisfaction. Personnel Psychology. 49. (4). Pp. 831-851.

Karidi, A. 1997. Characterization of Learning Culture from the Experience of Organizations. Tel-Aviv University.

Kearns, K. 1996. Managing for Accountability: Preserving the Public Trust in Public and Nonprofit Organizations. San Francisco, Jossey-Bass Publishers.

Kozlowski, S. W., \& Doherty, M. L. (1989). Integration of climate and leadership: Examination of a neglected issue. Journal of Applied Psychology, 74(4), 546-553. 
Little, M. L. and Dean, A. M. 2006. Correlations between Service Climate, Employee Commitment and Employees' Service Quality Capability. Managing Service Quality. 16. (5). pp. 460-476.

Litwin, G. H. and Stringer, R. A. (1968), Motivation and organizational climate, Cambridge, MA: Harvard Business School, Division of Research.

Mayer, D.M., Ehrhart, M.G., Schneider, B. (2009). Service attribute boundary conditions of the service climate-customer satisfaction link. Academy of Management Journal, 52.

Mulgan, R. 2003. Holding Power to Account: Accountability in Modern Democracies, Palgrave, Basingstoke.

Neal, A. and Griffin M.A., (2002), Safety Climate and Safety Behaviour, Australian Journal of management. Volume: 27 issue: 1.

Organ, D. W. (1988). Issues in organization and management series. Organizational citizenship behavior: The good soldier syndrome. Lexington, MA, England: Lexington Books/D. C. Heath and Com.

Pritchard, R. D., \& Karasick, B. W. (1973). The effects of organizational climate on managerial job performance and job satisfaction. Organizational Behavior \& Human Performance, 9(1), 126-146.

Ranft, A. L., Ferris, G. R and Perryman, A. A. 2007. Dealing with Celebrity and Accountability in the Top Job. Human Resource Management, 4, pp 671-82.

Roberts, N. C. 2002. Keeping Public Officials Accountable through Dialogue: Resolving the Accountability Paradox. Public Administration Review. 62. (6). pp. 658-669.

Robertson, D. A. 2004. Dictionary of Modern Politics. Third Edition, Europe Publications, Taylor and Francis Group, 3.

Romzek, B. S and Dubnick, M. J. 1994. Issues of Accountability in Flexible Personnel Systems. In New Paradigms for Government: Issues For the Changing Public Service, edited by. Ingraham, P. W and Romzek, B. S. San Francisco, CA: Jossey-Bass.

Romzek, B. S. and Dubnick, M. J. 1987. Accountability in the Public Sector: Lessons from the Challenger Tragedy. Public Administration Review. 47. (3). pp. 227-238.

Romzek, B.S. and Ingraham, P. W. 2000. Cross Pressures of Accountability: Initiative, Command, and Failure in the Ron Brown Plane Crash. Public Administration Review. 60. (3). pp. 240-253.

Rosenblatt, Z. 2006. The Construction and Cross-Validation of a Self-report Measure of Teacher Accountability, Presented at the annual meeting of the American Educational Research Association, San Francisco.

Schillemans, T. 2010. Redundant Accountability: The Joint Impact of Horizontal and Vertical Accountability on Autonomous Agencies. Public Administration Quarterly. 34. (3). pp. 300-337.

Schneider, B., 1975. Organizational climates: an essay. Personnel Psychology, Vol. 88, Issue 4. 
Schneider, B. and Bowen, D. E. 1993. The Service Organization: Human Resources Management Is Crucial. Organizational Dynamics. 21. (4). pp. 39-52.

Schneider, B., Macey, W. H., Lee, W. C. and Young, S. A. 2009. Organizational Service Climate Drivers of the American Customer Satisfaction Index (ACSI) and Financial and Market Performance. Journal of Service Research. 12. (1). pp. 3-14.

Schneider, B., White, S.S. and Paul, M.C. 1998. Linking Service Climate and Customer Perceptions of Service quality: Test of a Casual Model. Journal of Applied Psychology. 83. (2). pp. 150-63.

Scott, S.G., Bruce, R.A. (1994). Determinants of innovative work behavior: a path model of individual innovation in the workplace. Academy of Management Journal, 38, 1442-65.

Sparrow P R, Gaston K, 1996, Generic climate maps: A strategic application of climate survey data? Journal of organizational Behavior, Volume 17, Issue 6

Sparrow, P. R. (2001), 'Developing Diagnostics for High Performance Organization Cultures', in C. L. Cooper, S. Cartwright, and P. C. Earley (eds.), The International Handbook of Organizational Culture and Climate, pp. 85-106. Chichester: Wiley.

Tagiuri, R. (1968). The concept of organizational climate. W: R. Tagiuri I G. Litwin (red.) Organizational climate: exploration of a concept. Boston, MA: Harward University Press.

Tesluk, P E, Vance RJ, Mathieu JE (1999), Examining Employee Involvement in the Context of Participative Work Environments. Group and Organization Management, Volume: 24 issue: 3, pp. 271-299.

Tesluk, P. E., \& Mathieu, J. E. (1999). Overcoming roadblocks to effectiveness: Incorporating management of performance barriers into models of work group effectiveness. Journal of Applied Psychology, 84(2), 200-217.

Tetlock, P. E. 1985. Accountability: The Neglected Social Context of Judgment and Choice. Research in Organizational Behavior. Vol. 7. pp. 297-332.

Van Yperen, N.W., van den Berg, A. E., Willering M.C. (1999). Towards a better understanding of the link between participation in decision-making and organizational citizenship behaviour: A multilevel analysis. Journal of Occupational and Organizational Psychology (1999), 72, 377-392

Vigoda-Gadot, E. (2008). New public management values and person-organization fit: a socio-psychological approach and empirical examination among public sector personnel. Public Management, Vol. 86, issue 1.

Vigoda-Gadot, E., Cohen, H. (2015). Service satisfaction and organizational image: An empirical examination of the relationship with support for NPM-style reforms. Transforming Government: People, Process and Policy, Vol. 9 Issue: 1

Vigoda-Gadot E. and Drory A. (Eds.). 2016. Handbook of Organizational Politics: Looking back and to the Future. Cheltenham, UK; Edwars Elgar.

Vigoda-Gadot, E. and Mizrahi, S. 2008. Public Sector Management and the Democratic Ethos: A 5-Year Study of Key Relationships in Israel.

50 Review of International Comparative Management

Volume 20, Issue 1, March 2019 
Journal of Public Administration Research and Theory. 18. (1). pp. 79-07.

Vigoda Gadot E, Mizrahi, S, (2014). "Managing democracies in Turbulent Times: trust, performance and Governments in Modern States", Spriger Verleag Berlin Heidelberg

Walker, J. 2007. Service Climate in New Zealand English Language Center. Journal of Educational Administration. 45. (3). pp. 315- 337.

Wiley, Pugh and Dietz. 2004. Service Climate Effects on Customer Attitudes: An Examination of Boundary Conditions. The Academy of Management Journal, Vol. 47, No. 1 .pp. 81-92.

Wood, J. A. and Winston, B. E. 2007. Development of Three Scales to Measure Leader Accountability. Leadership and Organization Development Journal. 28. (2) pp. 167-185.

Wood, J. A. and Winston, B.E. 2005. Toward a New Understanding of Leader Accountability: Defining a Critical Construct. Journal of Leadership and Organizational Studies, 11. pp. 84-94.

Wright, B. E., Pandey S.K., 2011, Public Organizations and Mission Valence: When Does Mission Matter? Administration and Society, Vol. 43, issue 1.

Yitzhaki, R. and Friedman, Y. 2004. Perceived Teacher Accountability: Concept in the Multi-Dimensional Structure. Studies of Education Administration and Organization, 28, 161-193.

Ylimaki, R. M. and McClain, L. J. (2009). Wisdom-Centred Educational Leadership. International Journal of Leadership in Education. 12. (1). pp 13-33. 